\title{
LEGAL TRANSPLANTS AS TOOLS FOR POST-CONFLICT CRIMINAL LAW REFORM: JUSTIFICATION AND EVALUATION
}

John Jupp*

\begin{abstract}
The criminal law frameworks of countries that have been the subject of international peacekeeping operations and military interventions often reveal an urgent requirement for reform. The promotion of fair and effective justice systems, the rule of law and transition from conflict to peace frequently necessitates the introduction of new state legislation. Legal transplants have been employed as a legislative tool to bring about post-conflict legal change. However, the use of transplanted law in these situations has been controversial and has raised concerns about the justification for adopting it. This paper examines the justification for employing legal transplants to develop new post-conflict criminal laws by assessing their practical utility and the motivational rationale for employing them. It reviews theoretical perspectives on transplant feasibility and reflects on the experience of previous criminal law legal transplants. The article concludes by proposing an evaluative test for prior application to post-conflict criminal legal transplants to assess their prospects of success and to gauge the necessity for later change and adaptation.
\end{abstract}

\section{Keywords}

comparative law, post-conflict, criminal justice, legal transplants

\section{Introduction}

The legal frameworks of countries seeking to transition from conflict to peace are often subject to extensive reform following international intervention. The United Nations Assistance Mission in East Timor (UNTAET), for example, passed 71 legal regulations during its four year mandate. ${ }^{1}$ In Kosovo, 257 regulations were passed between 1999 and 2004, ${ }^{2}$ and in Afghanistan 188 new laws were enacted between 2003 and 2007. ${ }^{3}$ Many of these new laws were

\footnotetext{
Principal Lecturer in Law, London Metropolitan University.

1 UNTAET regulations. Available at: <http://www.unmit.org/legal/index-e.htm> [accessed 23 April 2014]

2 UNMIK regulations. Available at: <http://www.unmikonline.org/regulations/index.htm> [accessed 23 April 2014]

3 Data presented at the IV Joint Co-ordination and Monitoring Board Meeting, Berlin, 30 January 2007. Available at: $<$ http://www.moj.gov.af/?lang=en\&lang=en\&p=events\&nid=177> [accessed 23 April 2014]
}

Copyright $\odot$ the Author(s).

This work is licensed under a Creative Commons Attribution-NonCommercial-NoDerivs 3.0 License. 
introduced in order to improve local criminal legislation and facilitate the development of functioning criminal justice systems, regarded as central to post-conflict rule of law development. ${ }^{4}$ The intent, according to the United Nations $(U N)$, is that these systems should be equipped with operational courts, police, prosecution, judiciary and defence services, supported by government ministries and guided by procedural and substantive legislation. ${ }^{5}$ Achieving this ideal, however, presents an immense challenge in post-intervention states. The infrastructure and institutions necessary for the implementation of criminal justice are frequently damaged and limited in capacity. ${ }^{6}$ Existing domestic law, according to the UN, 'often show accumulated signs of neglect and political distortion, contain discriminatory elements and rarely reflect the requirements of international human rights and criminal law standards. ${ }^{7}$ The experience of criminal justice in states attempting to emerge from conflict is that domestic substantive and procedural law may fall short of sufficiently criminalising activities, allowing them to be committed with impunity and resulting in a weakening of efforts to establish the rule of law. In Angola, money laundering and corruption became endemic because they were not recognised as a criminal activity in any domestic law. ${ }^{8}$ Similarly, until the legal framework was amended by the special representative of the Secretary-General in 1999, kidnapping had been a common occurrence in Kosovo as the Kosovo Criminal Code failed to define it as an offence. ${ }^{9}$ In Afghanistan, poppy cultivation increased from 200 to 3,400 metric tons in the year following the removal of the Taliban from power in 2001. By 2003, the opium economy was valued at an estimated $\$ 2.2$ billion and it was financing destabilising armed factions. This prompted the passage of a Counter Narcotics Law ${ }^{10}(C N L)$ in the drive to establish an 'anti-drugs legislative

\footnotetext{
${ }^{4}$ According to the UN, the rule of law 'requires the protection of effective criminal justice measures': ECOSOC Res 2005/21; UNODC, The Criminal Justice Assessment Toolkit (2006). Available at: <http://www.unodc.org/documents/justice-and-prisonreform/cjat_eng/CJAT_Toolkit_full_version.pdf> [accessed 23 April 2014]

${ }^{5}$ Ibid.

${ }^{6}$ J Stromseth, D Wippman \& R Brooks, Can Might Make Rights? Building the Rule of Law After Military Interventions (2006) 247.

${ }^{7}$ Report of the Secretary-General: The Rule of Law and Transitional Justice in Conflict and Post-Conflict Societies, UN Doc 5/2004/616, 23 August 2004, para 27.

${ }^{8}$ C Rausch (ed), Combating Serious Crimes in Postconflict Societies: A Handbook for Policymakers and Practitioners (2006) 41.

9 Ibid, 41-2.

${ }^{10}$ Email correspondence, International Drugs and Development Adviser, 13 December 2008.
} 
system that meets international standards.' ${ }^{11}$

The frequent necessity for new criminal law in post-conflict states has resulted in a huge expansion of international interest and involvement in programmes designed to promote legal change through legislative reform in these environments. ${ }^{12}$ In addition to the UN, foreign assistance agencies such as the United Kingdom's Department for International Development and Germany's Agency for Technical Assistance have provided technical support for legislative drafting programmes in transitional states. Similar initiatives have been undertaken by non-governmental organisations such as the American Bar Association Central European and Eurasian Law Initiative (ABA/CEELI), the International Development Law Organisation and the International Legal Assistance Consortium, all of which have developed reform programmes and provided actors offering expertise in drafting legislative frameworks. ${ }^{13}$

While the development assistance these organisations provide demonstrates exemplary good will, the expanding practice in criminal law reform is indicative of a trend towards opportunism, noticeable during the post-conflict period, that is bent on changing the legislative status quo to ensure conformity with international human rights and due process standards. The critical period following the immediate cessation of conflict is, according to UN guidance, the perfect time for international legal advisors to 'set virtuous cycles in motion,, ${ }^{14}$ and develop effective criminal law frameworks conducive to establishing the rule of law. ${ }^{15}$ If this is indeed the case, it is vital to consider how legal change should be brought about.

The assumption by the international community of a central role in legislative reform in these states is a consequence of its custodianship of a new rights

${ }_{11}$ Transitional Islamic State of Afghanistan, National Drug Control Strategy, 18 May 2003, annex, v. Available at:

$<$

http://www.afghandata.org:8080/xmlui/bitstream/handle/azu/4328/azu_acku_pamphlet_hv5801_n385_2003_w.pdf> [accessed 23 April 2014]

${ }_{12}$ C T Call, Constructing Justice and Security after War (2007) 17.

${ }^{13}$ D Tolbert \& A Solomon, 'United Nations Reform and Supporting the Rule of Law in PostConflict Societies' (2006) 19 Harvard HRJ 29, 55-6.

${ }^{14}$ United Nations, Report of the Secretary-General on Peacebuilding in the Immediate Aftermath of Conflict, UN Doc A/63/881-S/2009/304 (11 June 2009) 1.

${ }^{15}$ S N Carlson, Legal and Judicial Rule of Law Work in Multi-Dimensional Peacekeeping Operations: Lessons Learned Study (2006). Available at: <http://www.unrol.org/files/Legal\%20and\%20judicial\%20RoL\%20work\%20in\%20multi\%20dimensional\%20pKping\%20operations\%20_Lessons\%20Learned\%20Study.pdf> 1-4, 18. [accessed 23 April 2014] 
framework, developed from transformations in human rights law and international criminal and humanitarian law since the Second World War, which has provided international actors with a perceived legitimacy in determining the normative content of required laws. ${ }^{16}$ Nevertheless, this legitimacy, and indeed the legitimacy of international interventions and consequent legislative reform programmes to establish the rule of law, is likely to be measured against the effectiveness of the laws and frameworks that are subsequently introduced. While the international interventions of the 1990s and 2000s were ostensibly motivated by humanitarian and national as well as international security concerns, their legitimacy in the eyes of local populations, judged against criticisms of invasion, imperialism and colonialism, can be dependent on the success of resulting new legislative reform that promotes the rule of law.

Any legitimacy risks being seriously undermined when mistakes are made. Delays by the UN Mission in Kosovo (UNMIK) in identifying an acceptable body of criminal law have been criticised for leading to violations of human rights norms and impairment to the credibility and legitimacy of international efforts to promote the rule of law in Kosovo. ${ }^{17}$ Care is needed in contemplating how criminal law reform should properly be conducted and received by local populations, requiring reflection on the most effective means of promoting legal change.

Recycling pre-existing criminal law may be an attractive solution. It is cost-efficient and may enhance much-needed legitimacy for a new government amongst the local population during difficult periods of transition and change. ${ }^{18}$ Difficulties can be encountered, however, when identifying existing criminal law, leading to confusion in application, a problem encountered in Afghanistan following 23 years of civil war and the destruction of legal texts by the Taliban regime. It may also be problematic locating suitable criminal codes capable of local acceptance. UNMIK's stipulation that the Serbian Criminal Code was to be applied in Kosovo was rejected by the Kosovar judiciary. In East Timor, the Timorese were dissatisfied with UNTAET's insistence on applying pre-existing

\footnotetext{
${ }^{16} \mathrm{~K}$ Boon, 'Legislative Reform in Post-Conflict Zones: Jus Post Bellum and the Contemporary Occupant's Law-Making Powers' (2005) 50 McGill LJ 285, 299.

${ }^{17}$ W S Betts, S N Carlson \& G Gisvold, 'The Post-Conflict Transitional Administration of Kosovo and the Lessons Learned in Efforts to Establish a Judiciary and Rule of Law' (2000-1) 22 Michigan JIL 371, 375 .

${ }^{18}$ R Z Sannerholm, In Search of a User Manual: Promoting the Rule of Law in Unruly Lands (2007). Available at: <http://papers.ssrn.com/sol3/papers.cfm?abstract_id=1068781> 8 [accessed 23 April 2014].
} 
Indonesian law. ${ }^{19}$ Applicable law may also be completely inadequate for domestic requirements, as was the case in Cambodia where the criminal law at the time of the establishment of the UN Transitional Authority in Cambodia (UNTAC) consisted of only one decree containing 12 brief articles. ${ }^{20}$

Legal transplants may offer an alternative solution. ${ }^{21}$ International experts have supported the transplantation of criminal law in the early stages of postconflict reform, ${ }^{22}$ and the UN has recommended the development of interim criminal codes for temporary application in generic post-conflict environments pending further reform. ${ }^{23}$ Transplanting law, moreover, may help to meet the requirements placed on occupying powers by Articles 43 and 64 of the Hague and Geneva Conventions to scrutinise and, if necessary, modify the legislation of occupied territories. Yet legal development involving the transplantation of foreign-designed law has also been criticised for embracing a technocratic 'one size fits all' policy that fails to sufficiently take into account important local legal traditions and socio-political influences. ${ }^{24}$ The controversy surrounding the use of legal transplants reflects a lack of certainty amongst the actors taking part in post-conflict reconstruction about their role in reform. This is epitomised in the contrasting recommendations of the 2000 UN Brahimi Report and the Rule of Law report published only four years later. While the former confidently advocated dependence on 'foreign models and foreign-conceived solutions,' the latter cautioned reformers to 'eschew one-size-fits-all formulas and the importation of foreign models.'

${ }^{19}$ V O'Connor, 'Rule of Law and Human Rights Protections through Criminal Law Reform: Model Codes for Post-Conflict Criminal Justice' (2006) 13(4) International Peacekeeping 517, 523.

${ }^{20}$ D A Donovan, 'Cambodia: Building a Legal System from Scratch' (1993) 27 The International Lawyer 445, 448.

${ }^{21}$ I employ the term legal transplant as a metaphor for the act of creating by means of borrowing, adopting, copying or imposing a legal institution, rule, law or legal norm established in one country and transplanting it into the legal system of another country. I use the words 'implanting', 'importing,' 'borrowing,' 'adoption', and 'legal transplantation' to refer to the same phenomenon. For terminology generally see E M Wise, 'The Transplant of Legal Patterns' (1990) 38 Am J Comp $L$ (Supplement) 1.

${ }^{22}$ J Dobbins, S G Jones, K Crane \& B C De Grasse, The Beginner's Guide to Nation-Building (2007) 77-9.

${ }^{23}$ Report of the Panel on United Nations Peace Operations: Comprehensive Review of the Whole Question of Peacekeeping Operations in All Its Aspects ('Brahimi Report') UN Doc A/55/305-S/2000/809 (21 August 2000), para 83. This advice supported the development of the Model Codes for Post Conflict Criminal Justice, a set of template criminal codes for legislative inspiration and transplantation.

${ }^{24}$ R Mani, Beyond Retribution: Seeking Justice in the Shadows of War (2002), 72. 
In spite of all the numerous attempts by international organisations to promote the rule of law and develop new legal frameworks since the 1990s, there remains insufficient knowledge and understanding about how legal change can effectively be facilitated. ${ }^{25}$ If international actors are drafting new laws to revise the criminal legal frameworks of states seeking to emerge from conflict as part of a general rule of law promotion agenda, they must consider how legal change can most effectively be achieved and, to that extent, whether there is any justification for adopting legal transplants.

This article considers this issue-transplant justification-in the context of post-conflict criminal law reform. It reviews the contribution of legal transplants to this field of law and the rationale for adopting them. It also examines academic literature on legal transplant feasibility and their limitations as tools for legal development. It finds that the motivational pull of legal transplants and their historical popularity provide justification for employing them as mechanisms for promoting legal change. It suggests that this justification is, nevertheless, dependent on the potential for any proposed transplanted law being successful, requiring clarity on the conditions for its success. Following a review of theoretical perspectives on the determinants of successful transplantation and the experience of previous criminal law transplants, this article concludes by proposing an evaluative test to determine the prospects of successful transplant reception and therefore the justification for employing the transplant mechanism to develop criminal law in post-conflict states.

\section{Legal Transplants and Criminal Law}

Following an examination of the transplantation of criminal evidence law from Anglo-American to continental jurisdictions, Mirjan Damaska concluded that in seeking inspiration for change, it is perhaps natural for lawyers to go browsing in a foreign law boutique. ${ }^{26}$ Legislators, it appears, frequently turn to legal transplants to solve legislative difficulties when creating new law. This is evident from the contribution of legal transplants to legal development across many legal disciplines and jurisdictions, including criminal law. The remarkable influence of the Napoleonic Code d'Instruction Criminelle (CIC) illustrates the power of the

\footnotetext{
${ }^{25} \mathrm{~K}$ Samuels, Rule of Law Reform in Post-Conflict Countries. Operational Initiatives and Lessons Learnt (2006). Available at: <http://siteresources.worldbank.org/INTCPR/Resources/WP37_web.pdf> 3. [accessed 23 April 2014]

${ }^{26}$ M Damaska, "The Uncertain Fate of Evidentiary Transplants: Anglo-American and Continental Experiments' (1997) 45 Am J Comp L 839, 852.
} 
legal transplant phenomenon as an instigator for legal development in this field. ${ }^{27}$ Within 60 years of its passage in 1808 , versions of it were transplanted into most of the criminal jurisdictions of continental Europe and it has served as a pervasive precedent for criminal justice reform around the world. ${ }^{28}$ The Italian criminal codes of 1808 and 1848 were heavily influenced by it, as were codes in Prussia in 1851, Russia in 1864 and Holland in 1867. ${ }^{29}$ Beyond Europe, its provisions were borrowed by Japan in $1882,{ }^{30}$ and it was a significant influence on criminal procedural reform during the $19^{\text {th }}$ and $20^{\text {th }}$ centuries in a number of Muslim countries. $^{31}$

Legal transplants have also been employed as mechanisms to reform inquisitorial criminal justice systems by introducing adversarial procedures. In a wave of post-revolutionary liberal idealism inspired by the French Revolution, a host of countries with inquisitorial traditions transplanted adversarial procedures during the $19^{\text {th }}$ century in order to introduce jury trials based on the English trial system into their own criminal systems. Jury trials were imported into French criminal procedure in 1789, and imported into Spain in 1820, Portugal in 1830, Germany in 1848 , Italy in 1860 and Russia in 1864 . In the $20^{\text {th }}$ century, they were re-introduced by means of legal transplantation in Russia in 1991 following considerable US influence, and in Spain in 1995 where the Anglo-American model was adopted. ${ }^{32}$ Italy also radically reformed its inquisitorial system by adopting significant adversarial procedures based on the Anglo-American model in its 1989 Code of Criminal Procedure. ${ }^{33}$ Similarly, Russia's Criminal Procedure Code 2001 borrowed models from western Europe and the United States, ${ }^{34}$ and incorporated Italy's plea-bargaining procedures. ${ }^{35}$ In addition, a number of eastern

\footnotetext{
${ }^{27} \mathrm{R}$ Vogler, A World View of Criminal Justice (2005) 59.

${ }^{28}$ Ibid, 58-9.

29 Ibid.

${ }^{30}$ A Watson, 'Legal Transplants and Law Reform' (1976) 92 LQR 79, 82.

31 The Ottoman Empire introduced a Penal Code in 1858 based on the CIC and a later procedural Code (1879) represented a translation of the French code. Persia's 1912 Criminal Code was also based on the CIC and Egypt's first criminal code (1882) was similarly dependent on it: see Vogler, above n 27, 115-18.

32 Ibid, 233-53.

${ }^{33}$ L Marafioti, 'Italian Criminal Procedure: A System Caught Between Two Legal Traditions', in J Jackson, M Langer \& P Tillers (eds), Crime, Procedure and Evidence in a Comparative and International Context: Essays in Honour of Professor Damaska (2008) 81.

${ }^{34}$ See generally L Orland, 'A Russian Legal Revolution: The 2002 Criminal Procedure Code' (2002) 18 Connecticut JIL 133.

${ }^{35}$ W Burnham, P B Maggs \& G M Danilenko, Law and Legal System of the Russian Federation (2004) 531.
} 
European countries have instigated or are currently in the process of undertaking similar reforms of their procedural codes to adopt adversarial procedures. Croatia, Bosnia and Herzegovina, Moldova and Georgia have all recently transplanted adversarial trial elements into their criminal procedures. ${ }^{36}$ Similar criminal procedure 'revolutions' have taken place in several Latin American jurisdictions over the last 20 years, assisted by legal transplantation. In 2003, Jonathan Hafetz estimated that 80 per cent of Latin American countries were involved in criminal procedure reform to replace their inquisitorial systems with adversarial ones. ${ }^{37}$ New criminal codes importing Anglo-American adversarial procedures by transplantation were introduced, for example, in Venezuela in 1998-1999, Chile in 2000, Ecuador and Bolivia in 2001 and Nicaragua and Honduras in 2002. ${ }^{38}$

Transplantation has also been prevalent in the context of criminal justice reform in post-conflict states, most recently in Afghanistan. The 98 articles of Interim Criminal Procedure Code 2004 (ICPC), for example, were largely sourced from the Italian Criminal Procedure Code 1988 and the provisions of both the 2003 and 2005 Counter Narcotics Laws were transplanted from UN 'model' laws. Moreover, Model Codes for Post Conflict Criminal Justice have been developed, ${ }^{39}$ comprising a compendium of draft laws and procedures for key elements of the criminal justice system-the courts, police and prisons-that are available for immediate transplantation in post-intervention states. This is an innovation that suggests that the way forward for criminal law reform in these environments is the transplantation of readily available foreign-designed codes. ${ }^{40}$

\footnotetext{
${ }^{36}$ D Krapac, 'Some Trends in Continental Criminal Procedure in Transition Countries of South-Eastern Europe', in Jackson, Langer \& Tillers (eds), Crime, Procedure and Evidence in a Comparative and International Context (2008) 119, 134; C Alkon, 'Plea Bargaining as a Legal Transplant: A Good Idea for Troubled Criminal Justice Systems?’ (2010) 19 Transnational Law and Contemporary Problems 355, 371.

${ }^{37}$ J Hafetz, 'Pretrial Detention, Human Rights, and Judicial Reform in Latin America' (2003) 26 Fordham ILJ1754, 1754-5.

${ }^{38}$ Vogler, above n 27, 172.

39 The Codes were developed from a project spearheaded by the United States Institute of Peace (USIP) and the Irish Centre for Human Rights in cooperation with the Office of the High Commissioner for Human Rights and the UNODC. They are divided between three volumes: volume I consists of a draft penal code, the Model Criminal Code; volume II a draft procedure code, the Model Code of Criminal Procedure; and volume III, the Model Detention Code and the Model Police Powers Act. The criminal procedure code contains more than 225 articles covering a range of issues from the investigation of crimes to trial and appeal proceedings as well as additional matters such as witness protection. See Stromseth, Wippman \& Brooks, above n 6, 198 .

${ }^{40}$ V O'Connor, 'Traversing the Rocky Road of Law Reform in Conflict and Post Conflict States:
} 
Legal transplants are indeed popular tools for developing criminal law. But their prevalence alone cannot fully explain why international actors engaged in post-conflict criminal law reform might have a 'natural' professional inclination for relying on them. There must be cogent reasons for their deciding to conduct reform in this way.

\section{Motivations for Transplanting Law}

Prestige, cost-saving, international harmonisation and modernisation are all important motivations for relying on legal transplants to develop law. According to Alan Watson, the motivation for borrowing foreign law-and indeed the prospects of the transplant being successful-is related to the degree of prestige that the new law carries. ${ }^{41}$ The prestige attached to a foreign import can satisfy that demand and the authority of a new law is less likely to be questioned if it has been borrowed from a foreign country where it has been successfully applied. ${ }^{42}$ In a similar vein, Watson has argued that transplanted law enhances the authority of those who administer it. ${ }^{43}$ The authority enhancing effect of transplanted law is a significant motivation for the borrowing of law. Michele Graziadei notes the influence of prestige on the recent adoption of German criminal law thinking among US scholars and concludes that 'prestige motivates imitation. ${ }^{\text {,4 }}$ The prestige attached to a law, which may relate to the particular legal system from which it derives, ${ }^{45}$ or to the perceived global importance of the law, provides it with the vital ingredient of legitimacy. ${ }^{46}$

There are, in addition, 'cost-saving' motivations for transplanting foreign law. They represent cheap and easy solutions to legislative problems that have occurred elsewhere. Legal transplants were notably welcomed as representing 'an easy, fast and cheap fix' during the optimism of the law and development move-

Model Codes for Post Conflict Criminal Justice As A Tool Of Assistance' (2005) 16 Criminal Law Forum 231, 247-55.

${ }^{41}$ See generally A Watson, 'Aspects of Reception of Law' (1996) 44 Am J Comp L 335.

${ }^{42}$ H Kanda \& C Milhaupt, 'Re-examining Legal Transplants: The Director's Fiduciary Duty in Japanese Corporate Law' (2003) 51 Am J Comp L 889, 890-1.

${ }^{43}$ Watson, above n 41, 335.

${ }^{44}$ M Graziadei, 'Transplants and Receptions', in Jackson, Langer \& Tillers, above n 33, 458.

${ }^{45}$ R Sacco, 'Legal Formants: A Dynamic Approach to Comparative Law (Instalment II of II)' (1991) 39 Am J Comp L 343, 398-9.

${ }^{46} \mathrm{~J}$ deLisle, 'Lex Americana?: United States Legal Assistance, American legal Models and Legal Change in the Post-Communist World and Beyond' (1999) 20 U Pa J Int'l Econ L 179, 280-1. 
ment in the 1970s. ${ }^{47}$ In the context of post-conflict criminal law reform, where there is often an urgent requirement for new legislation, their practical utility makes them attractive as means of quickly developing law. This motivation was acknowledged in the UN Brahimi Report in its recommendation for readilyavailable interim criminal code templates for deployment by 'quick response' legal teams. ${ }^{48}$ According to the Report, the application of an off-the-shelf 'interim legal code to which mission personnel could have been pre-trained' would have been beneficial to peacekeepers in Kosovo and East Timor. ${ }^{49}$ Afghanistan's transplanted ICPC was drafted in a short period of time in response to recommendations in international reports in 2003 that the procedural code required urgent reform. ${ }^{50}$ Similarly, the $2005 \mathrm{CNL}$ was prepared quickly with minimal local consultation to provide measures considered essential to counter the rapidly expanding illicit drug trade. According to a former Head of the UK Rule of Law team based in Afghanistan, the law was necessary 'in order to deal with the drugs problem, which was an immediate threat to security and stability in the country. Something needed to be fast-tracked in order to allow that to happen. ${ }^{51}$

Globalisation is also a significant motivational force for post-intervention criminal law transplants. Just as globalisation facilitates the expansion of transnational crime such as drug trafficking, at the same time it can guide the development of legislative processes to tackle it. Post-intervention states lacking suitable preventative law risk becoming safe havens for organised criminal and terrorist activity. The content of new law created to counter threats of this nature can be steered by the requirements of multilateral conventions, instruments and bilateral treaties that promote legislative similarity between signatory countries to enhance international co-operation in the investigation and prosecution of transnational criminal activity. The consequent drive for global legislative uniformity can be usefully accommodated by legal transplantation.

In addition, outdated laws in post-intervention states may need to be replaced by more 'modern' legislation equipped with tools to deal with contemporary criminal realities. UNTAC drafted a new criminal law for Cambodia, enacted by the Supreme National Council in 1992, to replace inadequate domestic

\footnotetext{
${ }^{47}$ L Nader, The Life of the Law: Anthropological Projects (2002), 48.

${ }^{48}$ Brahimi Report, above n 23, para 83.

${ }^{49}$ Ibid, para 81. See also M Plunkett, 'Re-establishing Law and Order in Peace-Maintenance', in J Chopra (ed), The Politics of Peace Maintenance (1998) 69.

${ }^{50}$ Amnesty International, Afghanistan: Re-establishing the Rule of Law (14 August 2003). Available at: <www.amnesty.org/en/library/info/ASA11/021/2003> para 7.5. [accessed 23 April 2014]

${ }^{51}$ Interview, senior member of the UK Rule of Law team, 29 February 2008.
} 
legislation. ${ }^{52}$ Bosnian criminal law lacked definitions for relevant crimes, such as corruption and money laundering, and failed to provide mechanisms to restrict these activities, such as the confiscation of profits, necessitating legal changes by a new criminal procedural code. ${ }^{53}$ Afghanistan's ICPC replaced a code that was nearly 40 years old and was designed, according to its drafter, to ensure that the country's criminal procedure system could be aligned 'with those of advanced democratic countries. ${ }^{54}$ In a similar manner, Afghanistan's CNL was designed to introduce modern investigative procedures into Afghanistan's criminal law framework in order to tackle increasingly sophisticated illicit drug production and trafficking. ${ }^{55}$

Whether prestige, cost-saving, globalisation or modernisation are implicated, one of the key objectives of employing legal transplants to facilitate criminal law reform in conflict states has been the necessity of ensuring compliance with international due process and human rights standards. The development since WWII of areas such as international criminal law, transitional justice and human rights law has created a globally recognised rights framework which influences the normative content of new domestic criminal law. New law must be consistent with internationally approved fair trial standards, such as those provided for in the International Covenant on Civil and Political Rights (ICCPR). This can be realised by transplanting provisions from foreign laws that already conform to these requirements. ${ }^{56}$ In East Timor, the UNTAET revoked sections of the existing Indonesian Criminal Code in 1991 that failed to comply with international human rights standards and later promulgated a more appropriate criminal law into which were transplanted provisions in tune with international human rights expectations. ${ }^{57}$ Similarly, in addition to modernising Cambodia's criminal justice system by providing new rules for detention, substantive law and procedure, UNTAC's new 1992 criminal code ensured the protection of citizens' human rights. ${ }^{58}$ Moreover, the ICPC was designed to provide a uniform criminal procedure for Afghanistan and at the same time guarantee compliance

\footnotetext{
${ }^{52}$ O'Connor, above n 19, 523.

${ }^{53}$ Call, above n 12, 250-3.

${ }^{54}$ IDLO, Criminal Law and Procedure in Afghanistan: Focus on Gender Issues (2007). Available at: <http://afghantranslation.checchiconsulting.com/documents/training/GenderAndCriminalJusticeTrainingMaterials_Dari_.pdf> [accessed 23 April 2014]

${ }^{55}$ Islamic Republic of Afghanistan, Counter Narcotics Drug Law [Afghanistan] 17 December 2005. Available at: <http://www.refworld.org/docid/4clf343b2.html> [accessed 23 April 2014]

${ }^{56}$ Boon, above n 16, 299.

${ }^{57}$ UNTAET Regulation no. 2000/30; O'Connor, above n 40, 240.

${ }^{58}$ O'Connor, above n 19, 524.
} 
with its international legal and human rights obligations. The development of these laws was facilitated by the adoption of legal transplants, highlighting their motivational attraction to legislators intent on ensuring that new criminal law in post-intervention states complies with international human rights and due process standards.

The variety of reasons why legal transplants are attractive mechanisms for legal development and the historical frequency with which they have been responsible for developing new criminal law would suggest that there is every justification for considering adopting them to promote legal change in post-conflict environments. Yet academic commentators on legal transplants have been unable to reach any universal agreement on their value for legal development. While this might appear to be anything but helpful when examining transplant justification, in fact the various theoretical perspectives on transplant feasibility provide useful insights on the legitimacy and constraints of legal transplants and require review. ${ }^{59}$ After all, if legal transplants can be adjudged to be valueless or even unfeasible tools for legal change, there is perhaps no justification for employing them at all.

\section{Theoretical Perspectives on Legal Transplants as Tools for Legal Change}

Much of the academic literature on legal transplants has been concerned with the association between a transplanted law and its importing and exporting environments. To a large extent, disagreements over the existence and feasibility of legal transplants have reflected conflicting perspectives over the relationship between law and the society in which it exists. ${ }^{60}$

Watson's controversial theory on legal transplants represents one extreme. His historical analysis of legal development and the prevalence of legal transplantation as a mechanism for promoting legislative change leads him to conclude that there is only a tenuous relationship between law and the society in which it operates, the significance of which is at best limited. ${ }^{61}$ The recipient system simply 'does not require any real knowledge of the social, economic, geographical and

\footnotetext{
${ }^{59}$ See generally H Xanthaki, 'Legal Transplants in Legislation: Defusing the Trap' (2008) 57 ICLQ 659.

${ }^{60}$ Kanda and Milhaupt, above n 42, 889.

${ }^{61}$ W Ewald, 'Comparative Jurisprudence: The Logic of Legal Transplants' (1995) 43 Am J Comp L 489, 491.
} 
political context of the origin and growth of the original rule. ${ }^{62}$ Law, for Watson, consists of prepositional statements and rules which have an autonomous existence separate from environmental concerns, affording them a nomadic character that enables them to be easily transplanted from one jurisdiction to another. Indeed, the many examples of successful borrowing and transplantation of legal rules over the course of legal history, rules which have not experienced change in their new environment, demonstrate the autonomous nature of law and its independence from external influences. ${ }^{63}$ Similarly, rules that might seem deeply entrenched in their political context are capable of being successfully transplanted to countries with quite different socio-political cultures, such as the adoption of French law into the Japanese Penal Code and Code of Criminal Procedure in $1882,{ }^{64}$ and the adoption of Italian law into post-conflict Afghanistan. The recurring advent of legal transplantation, Watson suggests, can be explained by the prestige that new laws and rules carry. Their architects, and thus the engineers of legal transplants, are generally elite lawyers, judges and legislators who insulate law from external influences, thus conspiring to further negate the value of wider national society to law. ${ }^{65}$

Pierre Legrand offers a perspective on transplant feasibility entirely at odds with that proposed by Watson. He asserts that legal rules are so dependent on the national environment in which they exist that they are incapable of travelling at all. For Legrand, law cannot be transplanted. Because legal transplants are 'impossible', post-conflict criminal law reformers must find other means of promoting legal change. ${ }^{66}$

Several other theories have been proposed on the existence, cause and relevance of legal transplantation as an explanation for legal development, which lie somewhere between the opposing views of Watson and Legrand, each offering different variations on the key factors that play a part in transplant feasibility. Most of these positions owe their heritage to Charles Montesquieu who, in the mid- $18^{\text {th }}$ century, declared that:

the political and civil laws of each nation should be so closely tailored to the people for whom they are made, that it would be pure

\footnotetext{
${ }^{62}$ Watson, above n $30,81$.

${ }^{63}$ See generally Watson, above $\mathrm{n} 41$.

${ }^{64}$ Ibid, 82.

${ }^{65}$ See generally A Watson, Failures of the Legal Imagination (1988) chs 1 \& 2.

${ }^{66}$ P Legrand, 'Legal Transplants', in D Nelken and J Feest (eds), Adapting Legal Cultures (2001) 57.
} 
chance [un grand hazard] if the laws of one nation could meet the needs of another $[. . .]^{67}$

Montesquieu's interpretation of the development of law has found resonance among a large number of theoreticians, who contend that law corresponds with societal features or is an expression of social interests or needs. ${ }^{68}$ Its growth and development, therefore, are dependent on any number of physical, cultural and political ingredients unique to the particular society it serves. ${ }^{69}$

Socio-legal theoreticians of this persuasion have a shared perception of law, not as a Watsonian autonomous entity, but as something that is relative, moulded by the society that it serves and by various itinerant features of that society. Law is bound so closely to its habitat by a potent mixture of physical, sociological, cultural and economic forces that it can rarely have validity in any other environment. ${ }^{70}$

This interdependence between law and society can, it would seem, make the adoption of foreign law problematic. While law may travel, the processes that foster and enable the trip are complicated and multifarious and dependent on stimuli that are more relevant than legal transplants alone for motivating and shaping legal change, such as society, culture, economy, ${ }^{71}$ politics and power. $^{72}$ Context is everything for legal development. ${ }^{73}$

What of Watson's stance on legal change? He advocates that the legal transplant is the one device that accounts for legal development. For Watson, there is every justification for developing post-conflict criminal law by resorting to legal transplants. That is how law develops. The baggage that might be known as 'societal influences' and 'local context' are largely inconsequential and can be discarded. This suggests that the post-conflict environment where the local economy may have collapsed, and where human, physical and institutional infrastructure are often devastated and where the legal system may be subject

${ }^{67}$ Charles de Secondat Montesquieu. De L'Esprit des Lois (1748), Book 1, Ch. 3, Des Lois Positives.

${ }^{68}$ See e.g. L Friedman,'Some Comments on Cotterrell and Legal Transplants', in Nelken and Feest, above n 68, 93-7; O Kahn-Freund, 'On Uses and Misuses of Comparative Law' (1974) 37 MLR 1.

${ }^{69}$ Ewald, above n 62, 491.

${ }^{70}$ W Twining, Lecture IV: Generalizing About Law: The Case of Legal Transplants' (2000) The Tilburg-Warwick Lectures. Available at: <http://www.ucl.ac.uk/laws/jurisprudence/docs/others/twi_til_4.pdf $>46$. [accessed 23 April 2014]

${ }^{71}$ Friedman, above n 68, 595.

${ }^{72}$ Kahn-Freund, above n 68, 13.

${ }^{73}$ G Teubner, 'Legal Irritants: Good Faith in British Law or How Unifying Law Ends Up in New Divergences' (1998) 61 MLR 16. 
to plural legal traditions is largely an irrelevance in the context of criminal law reform. Watsonian theory also appears to favour the Brahimi Report's support of 'foreign solutions' for legal development in post-conflict states and the use of readily-available draft laws from the Model Codes for Post Conflict Criminal Justice.

Although it is perhaps arguable that Watson's conclusions should only have application to the field of private law from which he draws most of his data, his contention that legal transplants are ubiquitous is difficult to rebut. Moreover, Watson's conviction that the antiquity of legal transplants demonstrates that they have been a major source of legal development is supported by the experience of many of the world's criminal justice systems. His work is undeniably useful for criminal law reformers in post-intervention states in that it at least encourages them to respect legal transplants as potentially viable promoters of legal change.

Where Watsonian theory is less useful is that it fails to properly consider what factors might be important for the successful transplanting of law. For the most part, Watson is non-committal on this issue. ${ }^{74}$ He prefers to concentrate on output rather than outcomes and has generally been more concerned with demonstrating that legal transplants are the primary source of legal development, ${ }^{75}$ than with the finer details of what may or may not make them successful sources. ${ }^{76}$ Ultimately, Watson's message for criminal legal reformers in post-intervention states would appear to be this: if you are creating new law you are certainly justified in considering employing legal transplants. In fact, this is how law develops. If you are also concerned about whether or not the new law will actually succeed, there is a presumption that it will, based on the experiences of legal history. The result is a bias towards transplant success and, ultimately, a theoretical stance that promotes transplant justification but which is fettered by the obvious criticism of unrealistic prejudice towards the effect and use of the legal transplant mechanism.

If the theories of Watson, Legrand and Montesquieu do not have all the answers to legal development, where does this leave us on the issue of transplant justification and post-conflict criminal law? It is perhaps more advantageous to balance the more constructive features of the various theoretical outlooks on legal transplantation rather than being concerned with their differences. Evidence from criminal law reform in post-intervention states and the motivational

\footnotetext{
${ }^{74} \mathrm{He}$ is not entirely atheoretical on the issue of transplant feasibility: see L McDonough, 'The Transferability of Labor Law: Can an American Transplant Take Root in British Soil?' (1992) 13 Comparative Labour LJ, 504.

${ }^{75}$ A Watson, Legal Transplants: An Approach to Comparative Law (1974) 95.

${ }^{76}$ Twining, above n 70, 40.
} 
rationale for employing transplants supports Damaska's observation that lawyers appear to be naturally inclined to transplant law to promote legal change. Indeed, as Richard Sannerholm maintains, "[c]harged with the task of supporting criminal law reform [...] [an] international expert would be hard pressed not to look at models and international benchmarks. ${ }^{77}$

It would seem that international actors drafting new law in post-intervention states are justified in considering using legal transplants to develop law, a position that positivist approaches such as Watson's would endorse. However, whether it is realistic for them to go on to do so depends on their potential for successful reception, an argument that draws on sociological positions that insist that legal development is inextricably linked to local context. This premise acknowledges a relationship between law and the society in which it exists. But if transplant justification is related to transplant evaluation, there needs to be some clarity on the variables that should be employed in order to measure the successful reception of a transplanted law.

\section{Transplant Evaluation}

A number of useful theories have been developed identifying the determinants for the successful transplantation of law and suggesting ways in which success can be measured. Otto Kahn-Freund has maintained that successful transplants can occur but it is the quality of the political relationship between the donating and recipient countries that determines their success or failure. Some rules which might have a weak connection to the socio-political structure of the society where they exist may be easily transplanted, whereas other rules with close connections to their socio-political environment are less likely to be transplantable. ${ }^{78}$ Thus, successful transplantation depends on new rules being put in and/or being taken from the right socio-political plot. ${ }^{79}$

Hideki Kanda and Curtis Milhaupt's views on transplant evaluation also emphasise the need to find 'the right plot'. For them, success is determined by the 'fit' between the adopted rule and the host environment. The nature of the fit depends on the complimentary relationship between the imported rule and the existing legal infrastructure in the host country (micro-fit), and between the

\footnotetext{
${ }^{77}$ Sannerholm, above n 18, 2-3.

${ }^{78}$ Ewald, above n 62, 495.

${ }^{79}$ Kahn-Freund, n 70, 11-13.
} 
imported rule and existing legal institutions of the political economy in the host country (macro-fit).

Daniel Berkowitz, Katharina Pistor and Jean-Francois Richard's analysis of the reception of transplanted law in 49 different countries during the $19^{\text {th }}$ and early $20^{\text {th }}$ centuries, a particularly useful contribution to the issue of transplant evaluation, revealed that transplanted law may work successfully if it contains principles familiar to the local population and if it is capable of adaptation by local users. ${ }^{80}$ Legal transplants that develop internally through a process of trial and error, innovation and correction, and with the participation and involvement of users of the law, legal professionals and other interested parties [...] tend to be highly effective. ${ }^{81}$ Transplant success is a socio-legal concern and necessitates the adoption of rules not unfamiliar to the recipient countries that are capable of further local change. ${ }^{82}$

The findings of Berkowitz et al resonate with those of Jacque deLisle following his assessment of the effect of US legal assistance programmes in former Soviet Bloc countries and China in the 1990s. deLisle concluded that the successful importation of legal transplants, while tied to their approximation with the legal culture of the importing country, could be facilitated by close collaboration between domestic and foreign legal experts, reliance on local expertise to determine the content of transplanted law and commitment by the importing country to implement its provisions. ${ }^{83}$

The conclusions by both Berkowitz et al and deLisle are insightful but perhaps their use in the context of assessing criminal law legal transplants, which are the focus of this article, is questionable. The majority of the legal transplants observed in both studies involved civil and commercial rather than criminal legislation. This reflects a trend among theories on transplant success and evaluation. None of the aforementioned theories have derived from evaluations of criminal law legal transplants, or indeed those connected to the reform of post-intervention criminal law frameworks. This is potentially significant because there is an important distinction to be drawn between civil law and criminal law transplants which may impact on evaluations of their success or failure. In the former, different forms of procedure, for example, are generally optional, diverse and not subject to determining international precepts. In the latter case, however, all transplantation led by international interlocutors

\footnotetext{
${ }^{80}$ D Berkowitz, K Pistor \& J-F Richard, 'The Transplant Effect' (2003) 51 Am J Comp L 163.

${ }^{81}$ Ibid, 189.

${ }^{82}$ Ibid.

${ }^{83} \mathrm{~J}$ deLisle, above $\mathrm{n} 46$.
} 
is subject to the imperative to respect international human rights norms. The international human rights framework provides benchmarks for the normative content of procedural criminal law. The provisions which ensure conformity with this framework, and with instruments such as the ICCPR, are not negotiable on 'cultural' grounds but are regarded as an absolute necessity irrespective of the economic, political or sociological environment of the receiving country. To that extent, if provisions included in transplanted criminal law are consistent with international human rights and due process standards, it is generally because they have to be included. There is no legislative choice on this issue. Therefore, it would be difficult to maintain that they should be judged against measurements of 'efficiency' or 'competition' or criticised to the extent that they 'find the right plot', 'fit' or have become 'unstuck'.

If we are to find a suitable means of evaluating the reception of transplanted criminal law, including post-intervention criminal law, and understanding the variables that might contribute to successful and failed reception, it is constructive to reflect on the experience of criminal legal reform that has involved legal transplantation. This provides further valuable insight into the determinants of transplant feasibility, useful for developing a suitable evaluative test for transplanted law that is designed to reform the criminal law frameworks of conflict states.

\section{Evaluations of Transplanted Criminal Law}

Evaluations of the effect of some of the legislation introduced by legal transplants during various law and development and rule of law promotion movements have revealed mixed results. The movement that witnessed the exportation of US law in the 1970s has been condemned by some commentators as a failure. ${ }^{84}$ Although driven by well-intentioned US academics and lawyers, it was undermined by adherence to arrogant assumptions of the effectiveness of laws and legal systems that were flawed, untested and found ultimately to be unsuitable. ${ }^{85}$

More recent legislative efforts to promote the rule of law in crisis and postconflict societies involving transplanting model templates have been criticised

\footnotetext{
${ }^{84}$ D M Trubek \& M Galanter, 'Scholars in Self-Estrangement: Some Reflections on the Crisis in Law and Development Studies in the United States' (1974) Wisconsin LR 1062, 1071-2; J N Rosenau, Turbulence in World Politics: A Theory of Change and Continuity (1990) 280.

85 Trubek \& Galanter, above n 87, 1075-7.
} 
as being 'disappointing, ${ }^{86}$ their potential for success reduced by a failure to understand important inter-relationships between law, norms and culture. Using Kosovo as a case study, Rosa Brooks argues that recent rule of law promotion efforts in crisis and post-conflict states have been typified by the transplantation of foreign formal law without proper prior consideration of the relationship in the recipient country between formal law and cultural norms. Brooks comments that:

[C]hanges in formal law matter where prevailing cultural norms say that formal law matters. But when formal law has little resonance for people, changes in formal law cannot by themselves create new normative commitments to the rule of law. ${ }^{87}$

This advice has been borne out with regard to the ICPC in Afghanistan. A state law based on Italian law and which failed to contain provisions drawing on procedural rules from Afghanistan's customary or Islamic legal traditions is largely ignored by legal actors who discretionally apply more historically relevant customary law and Shari'a to criminal cases.

A number of commentaries on criminal reform involving the transplantation of unfamiliar foreign models into established procedures have also revealed disappointing results. Many of these concern the adoption of adversarial procedures into the inquisitorial criminal justice systems of former Soviet Union republics. Jason Reichelt suggests that the introduction of plea-bargaining in the Republic of Georgia was a well-intentioned but ultimately ill-conceived transplant largely because it did not have a sufficiently equipped defence bar at the time of the adoption of the new system to render it fair and equitable. ${ }^{88}$ According to Reichelt, rather than the transplanted procedure achieving the desired effect of reducing trials, it increased the potential for corruption and alienated the public against the state justice system. ${ }^{89}$

A weak defence bar also hampered the successful transplantation of western European and US adversarial procedures into the Russian Criminal Procedure Code in 2001. Drawing from lessons from the Russian experience, Richard

\footnotetext{
${ }^{86}$ R Brooks, 'New Imperialism: Violence, Norms and the 'Rule of Law" (2002-2003) 101 Michigan LR 2285.

${ }^{87} \mathrm{Ibid}, 2322$.

${ }^{88} \mathrm{~J}$ Reichelt, 'A Hobson's Experiment: Plea Bargaining in the Republic of Georgia' (2004) 11(2) J East European L 159.

${ }^{89}$ Ibid, 187-188.
} 
Vogler maintains that the imposition of adversarial and due process norms by law on its own is unlikely to bring about significant procedural change. ${ }^{90}$ Cynthia Alkon reaches similar conclusions with regard to the transplantation of US-style plea-bargaining into the Moldovan criminal justice system. According to Alkon, this has amounted to a 'transplant failure' because of lack of support for the procedure by legal professionals. ${ }^{91}$

Other studies on criminal justice reforms involving transplantation offer more optimistic appraisals of transplants. Krapac suggests that some of the criminal law reforms conducted by European countries, notably Croatia, involving the adoption of adversarial procedures, have been successful. They have resulted in better human and defence rights protections that meet international standards. ${ }^{92}$ Davor Krapac also notes that new criminal law in these countries has often been subject to repeated amendment, indicating that legislators' initial choices of transplanted law may not always be realistic and may often be resisted. ${ }^{93}$ This is supported by the experience of criminal justice reform in Italy. The 1989 Code of Criminal Procedure imported significant adversarial features into Italy's inquisitorial system, but the model intended by the original reformers has since been eroded by the Constitutional Court and legislature. The Italian experience underlines the difficulties of transplanting procedures from different legal traditions. ${ }^{94}$ According to Luca Marafioti, 'different legal traditions and cultures foster different responsibilities within a system, thus encouraging different expectations, ${ }^{95}$ which may impact on whether or not a transplant is successfully received. Cultural resistance to a transplant may adversely affect the prospects of achieving its intended outcome. ${ }^{96}$ The same may be said of a lack of genuine commitment to reform amongst the legal authorities of the host country responsible for applying the provisions of any transplanted law introduced to promote legal change. ${ }^{97}$

Studies have also revealed that the existence (or not) of a culture of legality in the receiving country is also an important variable which can impact on transplant feasibility. No matter how potentially effective a transplanted criminal

\footnotetext{
${ }^{90}$ Vogler, above n 27, 185.

${ }^{91}$ Alkon, above n 36, 408.

${ }^{92}$ Krapac, above n 36, 141.

93 Ibid, 124.

${ }^{94}$ Marafioti, above n 33, 91.

95 Ibid.

${ }^{96}$ By way of example, the attempts to transplant the English criminal jury system on continental Europe after the French Revolution. See Damaska, above n 26.

${ }^{97} \mathrm{~J}$ Mertus, 'From Legal Transplants to Transformative Justice: Human Rights and the Promise of Transnational Civil Society' (1998-9) 14 Am U ILR 1335, 1383.
} 
law may be, its prospects of succeeding is likely to be reduced in societies where the legitimacy of state law and adherence to state concepts of criminal justice are weak. The transplantation of laws to promote criminal justice and the rule of law are less likely to be successful in the absence of a commitment to establishing these ideals.

What conclusions can be drawn from these examples of transplanted law to help determine the manner in which legal transplants intended to effect criminal justice reform in post-intervention states should be evaluated? Some criminal law transplants have been successful, while others have encountered reception difficulties, attributable to variables such as the capacity and commitment of legal professionals and the progress of related infrastructural and capacity-building reform efforts. The concept of success generally emerges, however, as controversial and difficult to measure. It may depend on whose point of view is considered. An international reformer may regard a law that they have drafted, dependent on foreign texts, as a success merely because it has been enacted, while a judge applying it may regard it as a failure. Furthermore, some aspects of transplanted laws may be successful, while others are not. It is difficult to judge accurately the effect of any law, let alone transplanted criminal law or the variable that will determine its success or failure. In this regard it is hard not to sympathise with Grazl's experience of 'the ubiquity of uncertainty during transplantation,' ${ }^{98}$ or to agree with Beckstrom's observation that ' $\mathrm{t}$ ] he identification of performance indicators for a transplanted legal system is a perplexing business as best. ${ }^{\prime 9}$

While acknowledging this, it is perhaps useful to note that the experience of legal transplants in the field of criminal law largely confirms Watsonian optimism over the significance of the legal transplantation medium for developing law. They also verify sociological perspectives of the centrality of local environment to legal development. Ultimately, they confirm the premise that law can develop by legal transplantation, but that the fundamental issue of whether or not they will succeed is tied to local contextual concerns. Furthermore, the weight of academic evidence in this field suggests that the criteria that are adopted for evaluating the success of any proposed or actual legal transplant must ultimately be fundamentally related to the environment into which the new law is imported. The same rule of thumb must apply for assessing legal transplants adopted for criminal law reform in post-conflict situations. Having said this, it is vital to

${ }^{98}$ P Grazl et al, 'The Choice in the Lawmaking Process: Legal Transplants vs. Indigenous Law' (2008). Available at: <http://ssrn.com/abstract+1130124> 5. [accessed 23 April 2014].

${ }^{99}$ J Beckstrom, 'Transplantation of Legal Systems: An Early Report on the Reception of Western Laws in Ethiopia' (1973) 21 Am J Comp L 557, 558. 
acknowledge that problems surrounding the reception of transplanted law in post-conflict states are likely to be symptomatic of the huge challenges that the state criminal justice system may face at the time of the enactment of the law. The poor capacity of legal personnel, potentially limited reach of the state system in countries such as Somalia and Afghanistan with plural legal traditions, corruption and insecurity are likely to impact negatively on transplant reception.

Perhaps when international reform and reconstruction efforts have had more time to 'bed-in', these negative effects can be reduced, allowing for better prospects of successful transplantation. Turkey's transplantation of the Swiss Civil Code was assessed as being successful, after all, some 25 years after the legislation was enacted. ${ }^{100}$ Moreover, at the time of its introduction, Turkey possessed a generation of well-trained jurists. Typical of post-intervention states, this was far from being the case in Afghanistan when either new criminal law was passed between 2004 and 2007. A UNAMA rule of law officer noted in 2007 that:

[W]e are starting at a low point. $40 \%$ of judges have no legal training at all. So it will take time for the new generation to come through. In many respects the foundations have been laid in terms of education and it will take time for the newly trained generation of lawyers to come through and make a difference. It will take at least a decade. ${ }^{101}$

It is likely that there will be a slower rate of progress in terms of legislative reform taking root in post-interventionist as opposed to non-conflict states, delaying the reception of any transplanted laws. According to Samuels:

It is increasingly clear that a realistic timeframe for re-creating a working criminal justice system following serious armed conflict with formal courts, trained judges and a retrained police force is close to twenty-years. This is all the more true where the criminal justice system was never particularly strong or effective before the conflict, and it is even worse where new legal norms are sought to be introduced, or if there is little political will or weak local constituency support for the reforms. ${ }^{102}$

\footnotetext{
${ }^{100} \mathrm{Ibid}, 582$ (n 94).

${ }^{101}$ Interview, Senior United Nations Assistance Mission in Afghanistan Rule of Law Officer, 17 October 2007.

${ }^{102}$ Samuels, above n 25, 18.
} 
What yardsticks should be adopted for evaluating post conflict criminal law legal transplants? What emerges from evaluative studies of legal transplants in general and from the experience of criminal law reform involving legal transplantation is that local environment matters. Success or failure is connected to local contextual concerns such as local ownership, participation and commitment to reform. Evaluations of legal transplants in post-intervention states must therefore be responsive to the idiosyncratic legal requirements of the country concerned at the time of its introduction and during the course of the evaluation, placed in the wider context of its legal traditions, cultural considerations and social, economic and political concerns. While these wider issues must be borne in mind, two key questions need to be addressed in order to evaluate the success of post-conflict criminal law legal transplants to assess transplant success. First, to what extent has the transplanted law been accepted by the local population of the recipient post-conflict country? And secondly, to what extent has it achieved the objectives for which it was enacted in the context of the post-conflict situation in which it was introduced? The greater its acceptance and the degree to which it has achieved its objectives the more successful it is as a transplanted law.

These two variables balance the socio-legal and positivist perspectives on law which have permeated academic discourse on legal transplants, the first reflecting the former and the second the latter. Answering them should help to determine whether there is any justification for adopting a legal transplant to promote legal change to a post-conflict criminal law framework. The greater the potential for the law being accepted and achieving its objectives, the greater the justification for developing it by adopting transplanted foreign provisions. In addition, the ongoing application of this test can help to ascertain whether or not there is any need for further amendment to the law.

A law's 'acceptance' can be determined with reference to its application. Objective performance indicators such as legal detention statistics, prison populations, and conviction and acquittal rates are informative in this respect if available and reliable. It is critical also to assess the application of a transplanted law by local law enforcement agents, judges, prosecutors and defence lawyers. This tallies with Beckstrom's observation during reform in Ethiopia that '[j] udges and lawyers practicing new laws are in the front line of the confrontation between new laws and the nation. The acceptance and effectiveness of the entire legal order depend in the first instance and for the most part on these men. ${ }^{103}$

The acceptance, and application, of a law by local practitioners is likely

${ }^{103}$ Beckstrom, above n 99, 561. 
to be heavily influenced by the extent to which they regard it as meaningful and appropriate for use in their own jurisdiction. According to Berkowitz, if legislation is to be effective, 'it must be meaningful in the context in which it is applied so citizens have an incentive to use the law. ${ }^{104}$ The more meaningful and appropriate local practitioners consider new legislation to be, the easier they will find it to understand, engage in and enforce, improving the prospects of its success. This, therefore, also requires assessment and will be largely conditioned by the compatibility of the new law with the established legal order and traditions of the host country, underlining the necessity of being sensitive to these variables prior to the transplantation of any law.

Assessing the extent to which a transplanted law's objectives have been achieved is also vital to its evaluation. This requires some analysis of the reasons for the demand for the law and the motivations for relying on the transplant mechanism to prepare it, which can impact on the achievement of objectives and therefore transplant success. Transplantation in the arena of post-conflict criminal law reform can often be motivated by expediency. The criminal justice systems in these states typically require urgent procedural and substantive reform. Yet 'cost-saving' legal reform involving transplantation may fail to be sufficiently sensitive to local legal traditions and context. The motivation of expediency may not guarantee success.

This is also the case with regard to transplants motivated by modernisation. Legal transplants designed to modernise post-conflict criminal justice systems often in reality reflect western and more particularly US motivations of promoting stability and combating concerns such as terrorism and international drug trafficking. This can be translated into legislative reform which, on the one hand, appears to augment criminal justice reform in conflict states requiring rule of law assistance, while on the other hand serves western and US foreign policy stabilisation interests. The requirement for rule of law reform can motivate US legal intervention and indeed hegemony, which has been articulated through agencies such as USAID and CEELI that actively promote US interests by dominating criminal procedure reform. However, it can also lead to reform that involves the transplantation of foreign-based law without any local participation. This can cause local resentment leading to the legislation being regarded negatively by local populations and politicised as impositions bent on imperialism and expansion. This perception can be increased when it competes with other practices in a country with plural legal traditions and when law reform is backed by military

\footnotetext{
${ }^{104}$ Berkowitz, above n 80, 167.
} 
force, which is often the case during rule of law promotion programmes in postconflict countries, such as that undertaken in Afghanistan. Visible foreign armies can provide coercive authority for lawmaking, but at the cost of local scepticism and contempt, which can undermine the ability of transplanted laws to achieve their objectives. This may well have been the case with the transplanted ICPC and the CNL in Afghanistan, the reception of which was problematic.

\section{Conclusion}

The post-conflict period can be an opportune time for promoting legal change, and criminal law frameworks are often a focus for reform to create functioning criminal justice systems, paramount for the establishment of the rule of law. While legal transplants have frequently been employed to develop new criminal law in post-conflict states, there is uncertainty over the justification for adopting them. Greater clarity on this issue of transplant justification may provide some guidance to post-conflict reformers on whether or not legal transplants represent practical solutions for promoting legal change.

The number and variety of motivational forces for legal transplantation certainly underline their practical significance and importance as a form of legal development. ${ }^{105}$ Moreover, the overwhelming historical evidence that legal transplants have been responsible for the development of new criminal law for a considerable period of time in many of the world's criminal justice systems demonstrates that it is, as Damaska observed, 'natural' for legislators to rely on them, particularly when engaged in the reform of criminal law frameworks of post-conflict states. Indeed, the ubiquity of legal transplants in the field of criminal law implies that it would be bad practice not to consider them as vehicles for developing new law. As Sannerholm maintains, "[c]harged with the task of supporting criminal law reform [...] an international expert would be hard pressed not to look at models and international benchmarks. ${ }^{\prime 106}$

While academic literature on legal transplantation reveals fundamental disagreement over transplant existence and feasibility, which reflect differences of opinion on the wider relationship between law and society, the more constructive aspects of these conflicting theories suggest that criminal law can certainly be developed by legal transplantation. This transplant justification is however dependent on the prior application of an evaluative test to determine the prospects of

\footnotetext{
${ }^{105}$ Kanda \& Milhaupt, above n 42, 889.

${ }^{106}$ Sannerholm, above n 18, 2-3.
} 
successful reception. The weight of evidence from evaluative studies of criminal law and theoretical assessments of transplant feasibility suggests that the success or failure of legal transplants will be intimately related to the local contextual concerns of the receiving countries at the time of their introduction and, subsequently, during their application. Bearing this in mind, evaluations of postconflict criminal law should assess the extent to which it is capable of being accepted and achieving their objectives. This entails examining the manner in which it will be applied by local practitioners, whether it has the potential to be regarded as meaningful and appropriate, the motivations behind its enactment and whether its objectives can be realised. The more positive the projected outcomes of the law relative to these criteria, the greater the justification for developing it by legal transplant. 